\title{
A Spreading of Receipts Formula for Creating a Capital Gains/Ordinary Income Brightline: Contract Termination Payments and Business-Versus-Investment Assets*
}

The chronic difficulty in achieving a cogent separation of capital gains from ordinary income ${ }^{1}$ has been particularly severe in two areas: (1) cases necessitating classification of payments received for termination of contract rights; ${ }^{2}$ (2) cases involving distinction between ordinary business and "other" (for example, investment) receipts for the purposes of section 1221(1) of the Internal Revenue Code. ${ }^{3}$ These areas present issues that are left unsettled both by current statute ${ }^{4}$ and by legislative intent. ${ }^{5}$ This Note will criticize existing judicial doctrines

- For critical guidance and encouragement, the author is deeply indebted to Boris Bittker, Robert C. Clark, and Bernard Wolfman. Partial support for this research was obtained from NSF Grants GS-2689, SOC76-24512, and SOC76-24394, as well as MCS7501493A01.

1. Chirelstein has put it succinctly: "In fact, as everyone knows, the elements of uncertainty surrounding the scope of the preference [for capital gains] have shown a tendency to multiply rather than dwindle with the passage of time." Chirelstein, Capital Gain and the Sale of a Business Opportunity: The Income Tax Treatment of Contract Termination Payments, 49 Minn. L. Rev. 1, 2 (1964). See B. BitTker \& L. Stone, Federal Income Estate and Gift Taxation 500 (4th ed. 1972); Miller, The "Capital Asset" Concept: A Critique of Capital Gains Taxation (pt. 1), 59 YALE L.J. 837 (1950); Surrey, Definitional Problems in Capital Gains Taxation, 69 HARv. L. REv. 985 (1956).

2. See [1977] 4 FED. TAXES (P-H) $\uparrow 32,117$ (listing cases pertaining to termination of contract rights). The complexity of the termination payments area is well illustrated by 60 Mich. L. Rev. 235 (1961).

3. See [1977] 4 FED. TAXES (P-H) IIf 32,071-76 (listing cases covering tax definition of stock in trade, inventories, and property held for sale to customers). See also id. If 32,358 70 (commodity futures and hedging transactions).

4. I.R.C. $\$ \S 1201-1254$.

5. For the history and legislative background of the capital gains system as introduced in the Revenue Act of 1921, see H.R. REP. No. 350, 67th Cong., 1st Sess., pt. 1, at 10-11 (1921); Thulin, The Capital Transaction Under the Revenue Act of 1921, 17 ILL. L. REv. 489 (1923). Miller, The "Capital Asset" Concept: A Critique of Capital Gains Taxation (pt. 2), 59 YALE L.J. 1057, 1057 n.I (1950), appropriately describes the original Committee Report as "elliptical." For the subsequent statutory evolution, see 1939-1 C.B. (pt. 2) 168, 176; Wells, Legislative History of Treatment of Capital Gains Under the Federal Income Tax, 1913-1948, 2 NAT'L TAx J. 12 (1949). 
that have been developed to govern the two lines of cases and will propose a single standard for both. The proposed standard is a mechanical one and relies on a mathematical measure that is calibrated to extend favored capital gains treatment to holders of long-term investments, that is, investments giving a gradual stream of returns over several years. This standard, which derives from an economic analysis of the lock-in problem, should be capable of solving most of the refractory classification problems that have historically plagued the two areas. $^{6}$

\section{Critique of the Traditional Judicial Doctrines}

Under the general rules of the present Code, ${ }^{7}$ disposition of an asset qualifies for long-term capital gain (and thus substantially reduced taxation) if three criteria are met: (1) the asset is a capital asset under section $1221 ;^{8}$ and (2) the disposition qualifies as a "sale or exchange"

6. The Note will not explore the various alternatives to the existing structure of capital gains treatment that are now under. consideration. See M. David, AlterNative Approaches to Capital Gains Taxation 109.15 (1968) (classification of reform strategies); S. SuRrey, Pathways to TAX Reform (1973) (capital gains reform placed in broader reform context); J. Green \& E. Sheshinski, Optimal Capital Gains Taxation Under Limited Information (Institute for Mathematical Studies in the Social Sciences, Stanford University, Aug. 1977).

7. I.R.C. $\$ \$ 1221-1223$.

8. The current text of I.R.C. $\$ 1221$ is as follows:

For purposes of this subtitle, the term "capital asset" means property held by the taxpayer (whether or not connected with his trade or business), but does not include-

(1) stock in trade of the taxpayer or other property of a kind which would properly be included in the inventory of the taxpayer if on hand at the close of the taxable year, or property held by the taxpayer primarily for sale to customers in the ordinary course of his trade or business;

(2) property, used in his trade or business, of a character which is subject to the allowance for depreciation provided in section 167, or real property used in his trade or business;

(3) a copyright, a literary, musical, or artistic composition, a letter or memo. randum, or similar property, held by-

(A) a taxpayer whose personal efforts created such property,

(B) in the case of a letter, memorandum, or similar property, a taxpayer for whom such property was prepared or produced, or

(C) a taxpayer in whose hands the basis of such property is determined, for purposes of determining gain from a sale or exchange, in whole or part by reference to the basis of such property in the hands of a taxpayer described in subparagraph (A) or (B);

(4) accounts or notes receivable acquired in the ordinary course of trade or business for services rendered or from the sale of property described in paragraph (I);

(5) an obligation of the United States or any of its possessions, or of a State or any political subdivision thereof, or of the District of Columbia, issued on or after March 1, 1941, on a discount basis and payable without interest at a fixed maturity date not exceeding one year from the date of issue; or

(6) a publication of the United States Government (including the Congressional 
under section 1222; ${ }^{3}$ and (3) the asset has been held longer than the statutory holding period under sections 1222 and $1223 .{ }^{10}$ Although each of these requirements may present ambiguities in application, ${ }^{11}$ the most basic difficulties are those surrounding the uncertain scope of the capital asset concept itself, and specifically the embodiment of that concept in the language of section $1221 .^{12}$ For example, section 1221 provides no guidance for determining the capital asset status of lumpsum payments for termination of contract rights. ${ }^{13}$ Also notable for its ambiguity is the classification into "business assets" (creating ordinary income) and "non-business assets" (creating capital gain) that is implied by the "sale to customers in the ordinary course of [a taxpayer's] trade or business" language of section 1221(l). The legislative history here supports the intention to establish some sort of division between "ordinary business receipts" taxable as ordinary income and "income from disposition of investments" taxable as capital gains, but the standard governing the division is far from specific. ${ }^{14}$

To attack these and similar problems, ${ }^{15}$ a variety of judicial standards has been devised to supplement the explicit coverage of section 1221 . These standards are by no means all consistent with each other and can frequently be limited to very specific facts. Within the maze of par-

Record) which is received from the United States Government or any agency thereof, other than by purchase at the price at which it is offered for sale to the public, and which is held by-

(A) a taxpayer who so received such publication, or

(B) a taxpayer in whose hands the basis of such publication is determined, for purposes of determining gain from a sale or exchange, in whole or in part by reference to the basis of such publication in the hands of a taxpayer described in subparagraph (A).

9. I.R.C. $\$ 1222(3)$ provides: “The term 'long-term capital gain' means gain from the sale or exchange of a capital asset held for more than one year if and to the extent such gain is taken into account in computing gross income."

10. The main provision is I.R.C. $\$ 1222$, see note 9 supra. I.R.C. $\$ 1223$ provides for "tacked" holding period in the substituted basis situation and a variety of other special situations discussed in B. BITTKER \& L. STONE, supra note 1, at 618-19.

11. See B. BitTiER \& L. Stone, supra note $\mathrm{I}$, at 608-12 (salc or exchange requirement); $i d$. at $616-19$ (holding period requircment).

12. See M. David, supra note 6, at 25; Surrey, supra note 1 , at 988.

13. See Chirelstein, supra note 1 , at $2-3$ (pointing to ambiguity of capital asset notion in I.R.C. $\$ 1221$ ).

14. See Miller, supra note 1 , at $860-78$ (distinction between business and investment as effectuated by Internal Revenue Code of $1939, \S 117(\mathrm{a})(1)$, the antecedent provision to the current I.R.C. $\$ 1221(1))$.

15. A background problem influencing the gencral interpretation of I.R.C. $\$ 1221$ is the perverse drafting of the statute to treat all property as a "capital asset" except as provided under $\$ 1221(1)$-(6), thus appearing to make the statutory exceptions the only gain categories to be treated as ordinary income. The effect is almost as if Congress had wished to create a presumption favoring taxpayers to the detriment of the Treasury, and the attempt to escape such an inference has colored the judicial efforts at $\$ 1221$ interpretation. 
ticularized theories and holdings, three major avenues of theoretical development can be discerned. ${ }^{16}$

First, there is the venerable "substitute for ordinary income" doctrine of Hort $v$. Commissioner, ${ }^{17}$ later amplified by Commissioner v. P.G. Lake, Inc. ${ }^{18}$ Under this doctrine, ordinary income treatment should apply to a lump-sum consideration received by the transferor of an asset when such consideration is merely a substitute for future income; only disposition of an asset "more substantial than" a right to future income may qualify for capital gain treatment. ${ }^{10}$

From an economic standpoint, this distinction makes little sense. ${ }^{20}$ An economically rational individual should be indifferent between direct ownership of a productive capital asset and a right to the future income stream produced by the asset over its future life. ${ }^{21}$ For this reason, the market value of the asset should be given by the best present estimate of the discounted present value of this future income stream, with the discount factor reflecting the riskiness of the projected re-

16. The three approaches should not be considered as either exclusive or exhaustive. In concrete situations, hybrid judicial approaches have been extremely common. See, e.g., Bisbee-Baldwin Corp. v. Tomlinson, 320 F.2d 929 (5th Cir. 1963) (combining substitute for ordinary income approach with Judge Friendly's equitable interest approach to contract termination payments). See also i S. Surrey, W. Warren, P. McDaniel \& H. Ault, Federal INCOME TAXATION 1051 (1972) (cases following Bisbee-Baldwin) [hereinafter cited as SURREY \& WARREN].

17. 313 U.S. 28 (1941). In Hort the taxpayer received $\$ 140,000$ from a tenant for cancellation of a lease. The Court held that the sum must be included in the taxpayer's gross income and was taxable at ordinary income rates.

18. 356 U.S. $260(1957)$.

19. The Hort-Lake approach may be expressed in terms of a fruit and tree metaphor, with the future income constituting the "fruit" and the underlying capital asset being the "tree." Such a metaphor had in fact been previously entrenched in the early cases governing tax treatment of income assignments. See Lucas v. Earl, 281 U.S. 111, 115 (1930) (Court will not sanction "arrangement by which the fruits are attributed to a different tree from that on which they grow"), ciled in Helvering v. Horst, 311 U.S. 112, 118 (1940) (taxpayer enjoys fruits of his investment whether he collects income or disposes of his right to do so). A summary of these cases is M. ChIRelstein, Federal Income Taxation 155-78 (1977).

20. See W. Hewitt, The Definition of Income and Its Application to Federal TaxaTION 27-28 (1925) (tree-fruit analysis not compelling in business transactions where property sold reflects admixture of "fruit" with "tree"); Eustice, Assignment of Income: Fruit and Tree as Irrigated by the P.G. Lake Case, 17 TAx L. REv. 295, 308-11 (1962) (similar).

21. An economic equivalence between capital stoek and the income stream it produces was argued by Irving Fisher early in this century:

In our picture, therefore, we observe (l) a stock of instruments existing at an instant of time, and (2) a stream of services through time, flowing from this stock of wealth. The stock of wealth is called capital, and its stream of services is called income. The income is the more important concept of the two, for the capital exists merely for the sake of the income, and the ownership of the capital has no other significance than the ownership of possible income from that capital.

I. Fisher, The Nature of Capital and Income 324 (1906) (emphasis added). The modern point of view is substantially the same, though typically expressed in much more formal terms, e.g., C. von WeIzsäcker, Steady State Capital Theory (1971). 
turn. ${ }^{22}$ Accordingly, under this economic calculus most-if not all ${ }^{23}$ business assets (including stock) should be excluded from the capital asset category under Hort, since these assets are "substitutes for ordinary income" given an appropriate discount factor. ${ }^{24}$ Unless one is prepared to rip up large areas of the settled legal landscape, Hort cannot be read literally, and the doctrine seems little more than a delegation to federal judges to do justice as they see fit.25

A second theory has crystallized around Corn Products Refining Co. v. Commissioner, ${ }^{20}$ whose holding has often been summarized as creating a distinction grounded on "business purpose" versus "investment purpose."27 Specifically, such a distinction would partition property sold or exchanged into two categories for tax purposes: "business property" disposed of in routine business operations, with gain or loss

22. See, e.g., K. Arrow \& M. Kurz, Public Investment, the Rate of Return, and OpTIMAL FISCAL POLICY 10-14 (1970) (foundations of discounting calculus in risk-free case); V. Brudney \& M. Chirelstein, Cases and Materials on Corporate Finance 63-66 (1972) (allowing for risk).

23. But cf. Searles, Adventures in Condemnation, Aesthetic Considerations and Unusual Elements of Value, 32 ALA. LAw. 392 (1971) (courts now considering aesthetic values in condemnation cases).

24. In the case of stock-the paradigm "general" capital asset-an accepted form of financial analysis identifies stock with the prospective stream of future dividends that it generates over the theoretically infinite future, and predicts share price as depending on the discounted present value of this stream. See M. FIRTh, The Valuation of Shares and the Efficient-Markets Theory 14-16 (1977); W. Lewellen, The Cost of Capital 88-93 (1969). A related valuation model would relate present share value directly to projected future corporate earnings rather than to dividends paid, see M. FIRTH, supra at 22-23. Of course, it has long been recognized that such "intrinsic value" models are overly simplistic in many cases, and may in particular do violence to market psychology in both bull and bear periods.

25. See Miller, Capital Gains Taxation of the Fruits of Personal Effort: Before and Under the 1954 Code, 64 YALE L.J. 1, 21-22 (1954) (reviewing efforts by lower courts to place limits on Hort for exactly this reason). Ultimately, the Hort doctrine derives from general judicial vigilance against the panoply of clever tax-avoidance schemes. See Chirelstein, Learned Hand's Contribution to the Law of Tax Avoidance, 77 YALE L.J. 440, 440441 (1968). See also Brodsky, Planning Business Transactions to Produce Capital Gains, 7 N.Y.U. TAX INST. 302, 319 (1949) ("If [the Hort] attitude should gain ground in the courts, it would be a mere matter of time before any scheme or device to convert ordinary income into capital gain would be doomed.")

26. 350 U.S. 46 (1955). The taxpayer in Corn Products, a manufacturer of goods made from grain corn, purchased corn futures, i.e., contracts to purchase a fixed amount of corn at a future date for a fixed price. The taxpayer disposed of the futures, and the Court held ordinary income rates applicable, because the transactions were found to be "in the ordinary course of business."

27. The usual, expansive reading of Corn Products is typified by Booth Newspapers, Inc. v. United States, 303 F.2d 916, 920 (Ct. Cl. 1962). For other developments of this expansive reading, see Schlumberger Technology Corp. v. United States, 443 F.2d 1115 (5th Cir. 1971) (purchase of stock and loans to new company to obtain services of certain in. dividuals); Steadman v. Commissioner, 424 F.2d I (6th Cir. 1970), cert. denied, 400 U.S. $869(1970)$ (advance of funds to corporation by attorney to protect his position as its secretary and general counsel); International Flavors \& Fragrances, Inc., 62 T.C. 232 (1974), rev'd, 524 F.2d 357 (2d Cir. 1975) (Corn Products application to gain on sale of pound-sterling short-sale contract, used to hedge investment in British subsidiary). 
on the disposition to be accorded ordinary income or ordinary loss treatment, and "investment property" held outside the daily course of business, with gain or loss to be treated as long-term capital gain or loss (if the "sale or exchange" and holding period requirements are met). Identical physical assets may thus be taxed in different ways depending on their relationship to the transferor's business operations. ${ }^{28}$

The fundamental difficulty with the Corn Products approach is that the postulated distinction has little independent meaning except as an artificial tax concept. ${ }^{29}$ Most businessmen would be puzzled by an attempt to split their transactions into nonoverlapping "business" and "investment" categories: most sound business decisions cover multiple objectives. ${ }^{30}$ Once multiple purposes are recognized, the mare's nest of finding a "dominant" motive is stirred up, as well as the problem of assigning weight to "substantial" motives found not to be dominant. ${ }^{31}$ Difficulties like these have caused even the most scholarly of commentators to remark that the field has come to resemble "tales from Mother Goose."32

An additional administrative problem produced by Corn Products is traceable to the taxpayer's advantage over the Internal Revenue Service (IRS) in access to information. When a taxpayer reports gain on the disposition of what is normally a capital asset, such as stock or securities, the Service cannot attack capital gains treatment without detailed knowledge of the taxpayer's business history and plans. The highly aggregated capital gains reporting schedule ${ }^{33}$ normally yields little foundation for such an attack, so that the Service can rarely em-

28. See examples developed in Cunnane, Acquiring Capital Assets for Noncapital Purposes, or When Is a Capital Asset Not a Capital Asset?, 29 N.Y.U. TAx INST. 705 (1971); Javaras, Corporate Capital Gains and Losses-The Corn Products Doctrine, 52 TAxes 770, 771 (1974); Troxell \& Noall, Judicial Erosion of the Concept of Securities as Capital Assets, 19 Tax L. REv. 185 (1964).

29. The inherent artificiality of any "business" versus "investment" distinction was early demonstrated by Miller, supra note 1 , at 860-78.

30. See A. Chandler, Strategy and Structure: Chapters in the History of the Industrial Enterprise 383.96 (1962); M. Zeleny, Multiple Criteria Decision Making, Kyoto 1975 (1976) (Springer Lecture Notes in Economics and Mathematical Systems No. 123).

31. In the closely related I.R.C. $\$ 1221(1)$ area, the leading "dual purpose" case is Malat v. Riddell, 383 U.S. 569 (1966), discussed in 1 SURREY \& WARREN, supra note 16, at 1013-16. See Bernstein, "Primarily for Sale": A Semantic Snare, 20 STAN. L. REv. 1093 (1969) (criticizing whole area and developing notion of "undecided purpose"). See also M. Chireistein, supra note 19, at 269 (emphasis on taxpayer's "motive" has led to much uncertainty). A further illustration of the horrors of "purpose" as a tax concept is United States v. Generes, 405 U.S. 93 (1972) (disallowing bad debt deduction because debt found to be more closely linked to individual's "role" as shareholder than to "role" as corporate employee).

32. Miller, supra note 1 , at 877 .

33. For a reproduction of Internal Revenue Service Form 1040, Schedule D, with annotations, see M. DAvid, supra note 6 , at 237-39. 
ploy Corn Products to increase revenue. ${ }^{34}$ By contrast, in the loss situation the doctrine is a taxpayer's weapon. Knowing his own finances in full detail, the taxpayer may be able to convert a capital loss into a fully deductible ordinary loss by theorizing that the loss was incurred as part of the conduct of some routine business operation. ${ }^{35}$

A third capital asset theory, which has seen application principally in contract termination cases, ${ }^{36}$ would predicate capital asset status on the nature of the transferor's property interest in the asset relinquished. Under this doctrine, developed by Judge Friendly, ${ }^{37}$ if the party giving up a contract right possesses a contract interest that would have been enforceable in a traditional court of equity, the right is then "substantial" and deserving of capital gains treatment on disposition. ${ }^{38}$ If, however, the party possesses an interest enforceable only at law, the right is "naked" or "insubstantial" and the disposition produces ordinary income. ${ }^{39}$

The distinction runs afoul of any economic justification of favored capital gains treatment. ${ }^{40}$ Distinctions based on subtleties of legal ownership have at most a weak and erratic effect on economic behavior by businessmen. Indeed, since at least the time of Charles Dickens' fictional Jarndyce $v$. Jarndyce, ${ }^{41}$ the shadings and gradations of owner-

34. See M. Chirelstein, supra note 19, at 270-71.

35. See note 27 supra (cases illustrating Corn Products application in loss situations).

36. See Note, The Troubled Distinction between Capital Gains and Ordinary Income, 73 YALE L.J. 693, 707-10 (1964).

37. See Commissioner v. Ferrer, 304 F.2d 125 (2d Cir. 1962) (Friendly's original statement); Sirbo Holdings, Inc. v. Commissioner, 476 F.2d 981 (2d Cir. 1973) (later amplification in situation where original contract was being modified, not terminated).

38. Commissioner v. Ferrer, 304 F.2d 125, 133-34 (2d Cir. 1962). The notion of linking capital asset status to a "more substantial property right" seems to have initially arisen in Commissioner v. McCue Bros. \&. Drummond, Inc., 210 F.2d 752, 753 (2d Cir. 1954). The Friendly equitable interest approach has understandably attracted widespread interest. For early responses to Ferrer, see Eustice, Contract Rights, Capital Gain, and Assignment of Income-the Ferrer Case, 20 TAX L. REv. 1 (1964); Freling, Sales of Intangible Business Assets, 14 TuL. TAx INST. 209, 225-30 (1965). On the complex remand history in Sirbo, see Note, Capital Gains Treatment of Restoration Payments: Sirbo Holdings, Inc. v. Commissioner of Internal Revenue, 7 CoNN. L. REv. 775, 775-91 (1975).

39. Commissioner v. Ferrer, 304 F.2d 125, 133-34 (2d Cir. 1962). There is a confused history attaching to the notion that certain contract interests may be enforced through equity, as by decree of specific performance, while other contract claims are enforceable only at common law, by damages for breach. Examination of the early seventeenthcentury British cases casts doubt on whether a clear notion of the limits of equity ever existed in the early law of contract. See Gray, The Boundaries of the Equitable Function, 20 AM. J. LEGAL Hist. 192 (1976). In American federal income taxation, the concept of the "naked" or "mere contract" right was introduced as a basis for denying capital gains treatment in Commissioner v. Pittston Co., 252 F.2d 344, 348 (2d Cir. 1958), discussed in B. BITTKER \& L. STONE, supra note 1, at 545-48.

40. See Blum, $A$ Handy Summary of the Capital Gains Arguments, 35 TAXes 247, 25360 (1957); pp. 736-40 infra.

41. Cf. C. Dickens, Bleak House 1-20 (Oxford Univ. Press ed. 1948) (literary portrayal of utter unintelligibility of various forms of action at common law). 
ship have been notorious for their incomprehensibility. Predicating tax treatment on such gradations therefore clashes with the basic objective of an economically rational tax system. ${ }^{42}$ An additional difficulty with the law/equity approach is that the "substantial rights" doctrine has no distinct content as federal law; rather, it depends on rights created under state law. ${ }^{43}$ Even though federal tax law may not be completely freed from state property law concepts, another major dependency seems undesirable. With such dependency, capital gains treatment will vary from Delaware to California and thus will compel courts to resolve dozens of substantive and conflict-of-laws questions about the local law governing each disputed transaction. ${ }^{44}$

The drawback shared by all three judicial doctrines is their emphasis on aspects of the transactions not normally a part of ordinary economic or business descriptions. Tax law thus is allowed to run on its own artificial logic, which is unrelated to economic or fiscal policy. In contrast to the three doctrines analyzed, this Note will attempt to draw a capital gains/ordinary income line that is compatible with the economic capital gains arguments.

\section{Economic Rationale for a New Theory}

Of the many justifications historically made for favored tax treatment of capital gains, the only compelling arguments are the economic ones. ${ }^{45}$ Specifically, these arguments stem from the public interest in

42. In fact, much of the conceptual apparatus surrounding the law/equity distinction is dissolving in the light of modern reevaluations of property law from an economic standpoint. See, e.g., Ackerman, Introduction, in Economic Foundations of Property Law (B. Ackerman ed. 1975); Demsetz, Towards a Theory of Property Rights, 57 AM. EcoN. REv. 347 (1967).

43. In principle, of course, a specialized tax doctrine of the law/equity distinction could be developed, much as existing tax law has developed a concept of earned surplus called "earnings and profits" to govern the taxation of dividend distributions. But to do so would create a morass of new law that one would go far to avoid. On the earnings and profits experience, see Andrews, "Out of Its Earnings and Profits": Some Reflections on the Taxation of Dividends, 69 HARv. L. REv. 1403 (1956); Zarky \& Biblin, The Role of Earnings and Profits in the Tax Law, 1966 S. CAL. TAX INST. 145.

44. Cf. Note, Problematic Definitions of Property in Miltistate Death Taxation, 90 HARv. L. REv. 1656 (1977) (similar problems arising in connection with state death taxes).

45. The original congressional intent that motivated enactment of the predecessor sections to I.R.C. $\$ 1221$ is very incompletely preserved in the available record, see note 5 supra, and in any event is of doubtful relevance as authority for resolving contemporary policy problems. Still less germane to that policy are the venerable arguments, traceable to the period immediately after the Civil War, that attempt to separate capital gains from the income concept altogether. See Gray v. Darlington, 82 U.S. (15 Wall.) 63 (1872) (profit on sale of government bonds found not to be income under language of Internal Revenue Act of 1867). By now, "income" is a purely functional concept that may be accorded as elastic a scope as necessary to bring virtually any gainful receipt into the scope of fully taxable income. See, e.g., J. SNeEd, The Configurations of Gross Income 63-68, 121-26 
promoting, and making efficient, investment activities in the private sector, $^{46}$ together with the recognition that high rates of ordinary income tax may create obstacles to such investment. ${ }^{47}$ For example, according to the traditional tax concept of "lock-in," full taxation of capital gains at high ordinary income rates may lock appreciated capital into those projects to which it was committed historically, thus preventing reallocation of that capital to uses generating higher rates of return. ${ }^{48}$ Although the importance of lock-in has recently been much debated, its economic significance is widely acknowledged. ${ }^{49}$ An econ-

(1967). Finally, the equitable arguments favoring taxation of capital gains at lower rates are unconvincing in a system where realization is wholly under the taxpayer's control and capital gains are principally realized in the higher income brackets. See Miller, supra note 5, at 1065-68; Tudor, The Equitable Justification for the Capital Gains Tax, 34 TAxes 643 (1956). See also A. Pigou, A Study in Publc Finance 156-64 (3d ed. 1974) (distributional aspects of taxes on windfalls).

46. For the economic arguments, see Blum, supra note 40, at 256-60; Miller, supra note 5 , at 1068-78. Underlying theoretical problems in the economic literature are reviewed by Shell, Sidrauski \& Stiglitz, Capital Gains, Income, and Saving, 36 REv. EcoN. STUD. 15 (1969). For empirical studies dealing with investment incentives and behavior, see $J$. Butrers, L. Thompson \& L. Bollinger, EFFects of Taxation: InVestments by INdividuals (1953); Jorgenson \& Siebert, An Empirical Evaluation of Alternative Theories of Corporate Investment, in Current Econometric Practice I55 (K. Brunner ed. 1972).

47. See Burnet v. Harmel, 287 U.S. 103 (1932), discussed in M. ChIRELstern, supra note 19 , at 257-58.

48. The lock-in effect can be derived mathematically. Consider an investor $I$ who currently holds an investment ("current investment $P$ ") that will generate future receipts having a discounted present value $R_{P}$. Producing this income are capital assets with a current market value $K_{P}$. Now consider a fresh investment opportunity (" $N$ "). $I$ 's total return on this new investment depends on the amount of capital he can sink in it. Assume, for simplicity, that the return is proportional to the amount of capital thus committed. Then $R_{w}$, the present value of the return from the new investment, equals $K r_{N}$, where $K$ is the amount of capital investment in the new opportunity and $r_{W}$ is the present value of the return per dollar of new investment.

Assuming that $I$ acts to maximize his return, he will shift his capital from Current to New if

$$
R_{z}>R_{p}
$$

Assume that $I$ faces a tax schedule $t=t(x)$ under which $t(G)$ is the average tax rate imposed on a realization producing $G=K_{P}-B_{P}$ dollars of gain, where $B_{P}$ is $I$ 's basis in the current investment and it is assumed that $K_{P}>B_{P}$ (appreciation of capital). Inequality (l) may then be rewritten

$$
\left(B_{P}+G(\mathbf{l}-t(G))\right) r_{L}>K_{P} r_{P},
$$

where $r_{P}$ equals return per dollar invested in the current investment. Lock-in will then always be present, assuming a positive tax schedule, and may be characterized by the following proposition:

If current fair market value exceeds basis $\left(K_{P}>B_{P}\right)$, any nonzero tax rate applied to gain on realization will cause rational investors to refrain from shifting their investment holding, when they would do so in the absence of taxation, if

$$
r_{X}>r_{P}>\frac{1}{K_{P}}\left(B_{P}+G(1-t(G))\right) r_{A} .
$$

Equation (3) characterizes the cases where efficient capital allocations will be impaired by taxation.

49. For studies tending to support the magnitude of lock-in, see Brown, The Locked-in Problem, in Federal Tax Policy for Economic Growth and Stability 367 (Joint Comm. 
ometric study by Feldstein and Yitzhaki ${ }^{50}$ supports the view that lock-in has a substantial impact on common stock trading. Using sample-survey data on portfolio behavior, ${ }^{51}$ these investigators found that even current rates of capital gains taxation strongly inhibit decisions to sell. Thus, an effective capital gains tax rate of fifteen percent reduces the ratio of sales to portfolio value by nearly fifty percent, and this is representative of effects present in other tax brackets. ${ }^{52}$ Given such sensitivity to a moderate rate of taxation, far more acute lock-in should be present if the same stock sales were taxed at ordinary income rates (seventy percent in the top bracket), and simulation results reported in the same empirical study support this intuition. ${ }^{53}$ Although transactions in physical capital may not be as sensitive to tax factors, the Feldstein-Yitzhaki results are highly supportive of the importance of lock-in. Pending further empirical research, tax designers should continue to assume that lock-in is a major hazard to be avoided.

Lock-in may not be the sole economic effect implicated in the decision to maintain a favored tax category of long-term capital gains..$^{54}$ However, preferring to calibrate the choice of a capital gains standard on a specific rather than a diffuse rationale, this Note postulates lock-in as fundamental and presents the capital gains tax design problem as one of minimization of lock-in subject to the revenue needs of the

on the Economic Report, 84th Cong., 1st Sess., 1955); Brown \&: Nichols, $A$ Deterrent to Investment Mobility, 25 FinaNcial ANALYSTs J. 131 (1969); cf. Waggoner, Eliminating the Capital Gains Preference: Part I. The Problems of Inflation, Bunching and Lock-in, 48 U. Cozo. L. REv. 313, 315 (1977) (lock-in is problem that must be addressed in considering structural reforms of existing capital gains system). But see Holt \& Shelton, The Implications of the Capital Gains Tax for Investment Decisions, 16 J. Finance 559 (1961); Sprinkcl \& West, Effects of Capital Gains Tax on Investment Decisions, $35 \mathrm{~J}$. Bus. 122 (1962). Lockin may be as much a psychological as an economic effect, and this may help to explain why the theoretical economic arguments tend to militate against the importance of lock-in while the available empirical data tend to support it. See, e.g., Sprinkel \& West, supra at 122 n.l. An excellent, neutral overview is the discussion in R. Goode, THE INDividual INCOME TAX 198-200 (rev. ed. 1976).

50. See M. Feldstein \& S. Yitzhaki, The Effect of the Capital Gains Tax on the Selling and Switching of Common Stock (Harvard Institute of Economic Research, Discussion Paper No. 532, Jan. 1977).

51. See D. Projector \& G. Weiss, Survey of Financial Characteristics of Consumers (1966) (description of data on which Feldstein-Yitzhaki study is based).

52. M. Feldstein \&. S. Yitzhaki, supra note 50 , at 13 .

53. Id. at 28-30. It should be noted that this finding only measures the impact of taxation on portfolio turnover and does not attempt to take the next step of quantifying the social welfare loss ensuing from such reduced turnover. For illustration in a different tax context of how such a calculation might proceed, sce Harberger, Efficiency Effects of Taxes on Income From Capital, in EFFECTS OF CoRporation INCOME TAX (M. Krzyzaniak ed. 1966); Shoven, Applying Fixed Point Algorithms to the Analysis of Tax Policies, in Fixed Points: Algorithms AND APplications 403 (S. Karamardian ed. 1977).

54. See Note, supra note 36 , at 695-701 (useful categorization of different possible economic concerns). 
Treasury. ${ }^{55}$ Specifically, this Note proposes the definition of a class of investments that are particularly sensitive to lock-in and should therefore be considered "capital assets" for purposes of favored tax treatment. 50

Favored tax treatment through the capital gains system should focus on private investors who decide to invest "long," that is, investors who acquire assets giving gradual financial returns over a long period following acquisition. ${ }^{57}$ Long investors are especially vulnerable to lockin, since they commit themselves to projects that are vulnerable to unforeseen changes in circumstances that, absent tax effects, would dictate abandoning the chosen project and reinvesting in another. ${ }^{58}$ This economic calculus applies equally to holders of long-term contract rights (such as lessors of oil rights) who are contemplating acceptance of lump-sum cancellation payments and to owners of longlife physical assets (such as machine tools) who are considering sale of those assets. In addition, the anticipation of lock-in can deter current investment in long-term capital stock of all kinds, for reasons that are both economic and psychological. ${ }^{59} \mathrm{~A}$ policy of favoring long investors

55. In economic terms, the capital gains definition problem is now being conceived as a constrained optimization problem, where the constraint ("revenue need") is the outcome of a higher-level policy choice, reflecting level of government expenditure and level of deficit financing. For policy factors surrounding this higher-level choice, see R. Musgrave \& P. Musgrave, Public Finance in Theory and Practice 587-610 (2d ed. 1976). But see A. Wildavsky, The Politics of the Budgetary Process xvi (2d ed. 1974) (impossibility of effecting perfect separation between tax policy and expenditure policy).

56. This definition presents a policy goal that would approximate the minimization of lock-in. To solve the minimization problem rigorously, one should ideally seek a measure of the welfare loss resulting from each possible configuration of capital gains and ordinary income taxes. However, formal theory in this area remains in an early stage and in any case is unable to incorporate the transactions costs inhering in any major departure from the existing system. See M. Feldstein, The Welfare Cost of Capital Income Taxation (unpublished paper, Dep't of Economics, Harvard University, revised Mar. 1977)); J. Green \& E. Sheshinski, Approximating the Efficiency Gain of Tax Reforms (Harvard Institute of Economic Research, Discussion Paper No. 516, Nov. 1976).

57. The "long" investment concept here would generalize the notion of the "length" of an investment used to classify bonds along the liquidity spectrum. See C. Nerson, The Term Structure of Interest Rates (1972); B. Friedman, Substitution and Expectation Effects on Long-Term Borrowing Behavior and Long-Term Interest Rates (Harvard Institute of Economic Research, Discussion Paper No. 495, Aug. 1976).

58. One major source of such changed circumstances is, of course, uneven inflation im. perfectly anticipated by investors. See D. Foley \& M. Sidrauski, Monetary and Fiscal Pol.Icy in a Growing Economy 203-24 (1971). Such inflation is at once a significant source of changing relative rates of return and also a source of significant asset appreciation whose spurious nature will not be reflected by the existing tax structure. On inflationary aspects of lock-in, see Blum, supra note 40, at 255-56; Brinner, Inflation, Deferral, and the Neutral Taxation of Capital Gains, 26 NAT'L TAx J. 565, 571-73 (1973).

59. On deterrence of investment through "prospective" lock-in, see Note, supra note 36 , at $697-98$. 
thus responds to the tendency of the Western economies to exhibit chronic shortages in private investment in long-term capital goods. ${ }^{60}$

In defining "capital" investments for a variety of tax purposes, ${ }^{01}$ it has been traditional to seek the essence of capital in the physical nature of the asset and in the social relations surrounding it. For example, one major body of case law predicates capital gains treatment on whether or not the asset is traceable to the taxpayer's "personal efforts," with an affirmative answer justifying taxation as ordinary income. "This Note rejects such an approach and instead takes the position that "long" investments are most appropriately characterized in purely financial terms. An asset should be identified with the stream of cash or cashequivalent gross receipts generated by it over its productive lifetime. The distinguishing financial characteristic that identifies a capital asset is the extent to which this stream of receipts is dispersed over time (the intertemporal "spreading of receipts"). ${ }^{63}$ The model of a capital asset is the piece of productive machinery turning out marketable machine parts over a ten-year period. The model of the ordinary income asset, on the other hand, is the inventory item whose sale generates an isolated cash receipt. Between these extremes is a grey area comprising, for example, fast-depreciating equipment. ${ }^{64}$ As these examples indicate, "capital" is to be defined solely through the prism of financial structure, without examining the source of the receipts in any way.

60. The classical theoretical prediction of such a long-investment shortfall is, of course, J. Keynes, The General Theory of Employment, Interest, and Money 27-31, 248-53 (1936). Within the legal and fiscal policy literature, the capital shortage problem is analyzed by B. Bosworth, J. Duesenberry \& A. Carron, Capital Needs in the Seventies (1975); Jones, The Need for Capital, 28 NAT'L TAX J. 265 (1975). Of course, capital gains policy is by no means the sole policy through which an investment shortage might be met. See, e.g., S. SurReY, supra note 6, at 206 (recommending use of investment credit mechanism as "flexible macroeconomic tool").

61. Outside the capital gains area, another capital definition problem arises in secking to achieve a stable demarcation between I.R.C. $\$ 162$ (a) and I.R.C. $\$ 263$ (deductible business expenditure versus nondeductible capital expenditure).

62. See, e.g., I.R.C. $\$ 1221(3)$. The "common law" of federal income taxation has also long denied capital gains treatment to payments received for contract termination when the contract involved personal services rendered by the taxpayer, or performance under the contract could be traced to such services. See McFall v. Commissioner, 34 B.T.A. 108 (1936); Miller, supra note 25, at 16-19. See also [1977] 4 FED. TAXEs (P-H) II 32,099.15 (tax treatment of amount received by employee for cancellation of employment contract); $B$. BITTKER \& L. StONE, supra note $\mathrm{I}$, at 550-51 (subsequent developments).

63. See J. Hicks, Capital and Time: A Neo-Austrian Theory 14-26 (1975) (concept of "time-profile" of capital asset); Chirelstein, supra note 1, at 27-28 (position of lessor analogized to position of bondholder); Note, supra note 36 , at 714-15 ("continuing stream of income" as appropriate general standard for capital asset status). The intellectual debt owed by this Note to the last source is particularly to be acknowledged.

64. See I.R.C. $\$ 167$ (b). However, one should distinguish the legally allowed rate of depreciation from true depreciation when fast depreciation is a tax subsidy. For criticisms directed against this tax subsidy practice, see Samuelson, Tax Deductibility of Economic Depreciation to Insure Invariant Valuations, 72 J. Political Econ. 604 (1964), reprinted in 3 The Collected Scientific Papers of Paul A. Samuelson 571 (R. Merton ed. 1972). 


\section{Proposed "Spreading of Receipts" Standard}

The new capital asset standard requires a test to determine in specific cases which investments are "long" and which are not. ${ }^{65}$ Although the theoretical rationale furnishes a general way of rethinking the entire capital gains/ordinary income line, this Note proposes a mechanical, "brightline" test ${ }^{06}$ to cover contract termination problems and classification problems arising at the boundary of section 1221(1), the "ordinary course of business" requirement. ${ }^{67}$

It is recommended that the standard should at first be embodied experimentally in Regulations issued under a new enabling statute analogous to section 1502 in the consolidated returns areas. ${ }^{68}$ Such a strategy seems preferable to immediate amendment of section 1221 since flexibility is thereby preserved: difficulties with the new standard may be eliminated through amended Regulations far more readily than they may be exorcised from the Code itself, and prior embodiment of new ideas in the Regulations is a recognized route to eventual elevation to the Code. ${ }^{60}$

\section{A. Theoretical Development}

The new standard can be explained in three steps: (I) identify the transferred asset with the income stream it generates; (2) evaluate the "spreading of receipts" in this stream by a mathematical formula and characterize the asset as a "capital" asset if this spreading exceeds a

65. The mathematical reader is directed at once to note 81 infra for statement of the proposed mathematical rule.

66. A brightline standard is any clear rule that yields a predictable, definite legal result when presented with adequate factual data.

67. See pp. 729-30 supra.

68. Modifying the language of I.R.C. $\$ 1502$ to fit the present situation, the text of a possible enabling provision could be:

Section 1221A. Regulations.

The Secretary or his delegate shall prescribe such regulations as he may deem necessary in order to clarify the application of section 1221 in delineating the scope of the capital gains preference.

Such a statute seems necessary to give the proposed Regulation, see Appendix infra, a proper authority when its application may lead to results inconsistent with Supreme Court opinions such as Hort v. Commissioner, 313 U.S. 28 (194I).

69. The utility of well-designed Regulations is not to be underestimated. The so-called Clifford Regulations, Treas. Reg. 118, $\$ 39.22$ (a)-21, T.D. 5488 (1945), largely settled the potentially endless issues surrounding choice of taxable person in grantor trusts that had been presented as a sequel to Helvering v. Clifford, 309 U.S. 331 (1940). See Surrey, The Supreme Court and the Federal Income Tax: Some Implications of the Recent Decisions, 35 ILL. L. REv. 779, 807-13 (1941). Nine years elapsed before statutory resolution was ultimately provided by I.R.C. $\$ \S 671-679$. See Eisenstein, The Clifford Regulations and the Heavenly City of Legislative Intention, 2 TAx L. REv. 327 (1946) (favorable to Regulations). See generally Griswold, A Summary of the Regulalions Problem, 54 HARv. L. REv. 398 (1941) (potential of properly used tax regulations for reducing tax uncertainty and litigation). 
specified threshold; (3) accord the capital gains preference to dispositions of assets determined to be capital that also meet the sale or exchange and holding period requirements.

\section{Identification of Asset with Income Stream}

Two segments of the income stream require separate evaluation: ${ }^{70}$ (1) the historical stream of past receipts attributable to the asset while in the hands of the present owner; ${ }^{71}$ (2) the projected future stream of receipts, to be calculated as if the asset were continuing in the disposing owner's hands. ${ }^{72}$ Both streams must be computed or estimated with respect to some fixed accounting period. A quarterly period will be used unless otherwise specified.

With respect to both past and future streams, it will often be necessary to assign to the asset ${ }^{73}$ a proper share of an overall return attributable to some larger constellation of productive assets. ${ }^{74}$ With respect to the future stream only, the same uncertainties of projection will arise

70. Mathematically, the complete stream $R_{1}, R_{n}, \ldots, R_{n}, R_{n+1}, \ldots, R_{L}$ is obtained by joining the past (historical) stream $R_{1}, R_{2}, \ldots, R_{n}$ to the future (projected) stream $R_{n+1}, \ldots, R_{L}$, where $R_{i}=$ receipts in accounting period $i$. Here the disposition occurs in period $n$ and $L$ is the number of accounting periods in the full lifetime as measured from the point of acquisition by the disposing owner.

71. Observe that no requirement is imposed that the current owner must trace receipts accruing to past owners of the asset. Contrast the "tack-on" approach followed under I.R.C. $\$ 1223$ with respect to the holding period in the substituted basis situation, see note 10 supra.

72. The future portion of the stream is to be calculated without allowing for repair or other replacement investment. Under the approach taken in this Note, inflation would also not be taken into account, i.e., there would be no attempt to "index" future receipts to adjust them to the current price level as of period $n$.

73. In referring to "the" asset, an aggregation problem arises whenever several assets are disposed of in one transaction. The component assets may be tested separately from capital asset status under the spreading measure, see pp. $744-45$ infra, or may be lumped together and characterized collectively through application of the spreading measure to the aggregate stream of receipts. As under existing law, the tax result may vary depending on which of these two approaches is followed. Compare Commissioner v. Ferrer, 304 F.2d 125, 131 (2d Cir. 1962) (Judge Friendly's "fractionating" approach to aggregation problem in contract interests) with Williams v. McGowan, 152 F.2d 570 (2d Cir. 1945) (Judge Learned Hand's integrating approach when asset sold was entire business). See also M. Chrrelstein, supra note 19, at 287-93 (review of competing judicial approaches in this field).

74. Two related valuation problems should be noted. First, when not all output from a productive asset (e.g., a machine tool) is immediately saleable owing to lack of effective demand, the value of the receipts attributed to the asset in a given period should be the fair market value of output produced, not output actually sold in that period. Such an approach is consistent with the objective of preventing tax policy from unwittingly abetting a Keynesian economic contraction. See, e.g., A. LeIjonhufvud, ON KEYNESIAN Economics AND THE ECONOMICS of KEYNES 49-109 (1968). Second, transactions not at arms-length constitute an inevitable source of problems as in all valuation situations. See R. PAuL, Studies IN Federal. Taxation 228 (1937). These transactions will require judicial discretion, see pp. 754-55 infra. 
that trouble Chapter $\mathrm{X}$ cases. ${ }^{75}$ In contrast to Chapter $\mathrm{X}$ valuation, however, no discounting to present value is required, and thus no choice of capitalization rate (with its attendant uncertainties and instabilities) need be made or defended. ${ }^{76}$ The uncertainty concerning the magnitudes of future receipts may also be mitigated by adapting a throwback rule in the present situation. ${ }^{77}$

\section{Mathematical Evaluation of the Spreading of Receipts}

In a contract termination payment or section 1221(1) case, capital asset status is to be accorded to an asset on disposition if and only if the dispersion of receipts, calculated mathematically by a formal measure introduced below, exceeds a fixed threshold imposed by the Regulations.

First, given the stream of past and projected receipts, total receipts may be computed, as may the proportion of those receipts falling in any past or future accounting period. ${ }^{78}$ From these proportions one first ascertains the average deferral time for a dollar of receipts from the asset, evaluated by measuring from the time of acquisition of the asset by the disposing owner. ${ }^{72}$ Thus, if the owner must wait a single period for a certain fraction of the receipts, two periods for a second fraction, three periods for a third fraction, and so on, it is possible to

75. See Consolidated Rock Prods. Co. v. Du Bois, 312 U.S. 510 (1941); King, Chapter X Valuation: Principles and Applications, 42 NAT'L $J$. Conf. REF. BANkruptcy 108, 110 (1968).

76. V. Brudney \& M. Chirelstein, supra note 22, at 73-77 (problem of valuing small company undergoing Chapter $\mathrm{X}$ reorganization). See also Brennan, An Approach to the Valuation of Uncertain Income Streams, in CapITAL MARKET Equilibrium ANd EFficiency 351 (J. Bicksler ed. 197\%) (mathematical model attempting to improve reliability in this situation).

77. See pp. 756-57 infra.

78. In the notation of note 70 supra, total receipts will be

$$
T=R_{1}+R_{2}+\ldots+R_{L}
$$

(adding total past stream to total projected future stream). The proportion $r_{i}$ of receipts falling in period $i$ is represented by $r_{i}=R_{i} / T$. This quantity may also be interpreted as the probability that a randomly chosen dollar of receipt attributable to the asset will be realized in period $i$.

79. Mathematically, this average deferral time $M$ is given by the formula

$$
M=\sum_{i=1}^{L} i r_{b}=r_{1}+2 r_{2}+3 r_{3}+\ldots+L r_{t}
$$

where the symbol $\underset{i=1}{L} i r_{1}$ is to be read "the sum from period 1 to period $L$ of the quantities $i$ multiplied by $r_{i}$ " and the $r_{i}$ are as specified in note 78 supra. On the notation, see F. Mosteller, R. Rourke \& G. Thomas, Probability with Statistical applications 417-26 (1961). 
compute how many periods, on the average, the investor must wait for a dollar of receipt. ${ }^{80}$

Given this average deferral time, the next step is to measure the degree of spreading of deferral times around the average deferral time. Mathematically, this problem can be solved by calculating the statistical standard deviation of the waiting times for dollars of receipts. ${ }^{81}$ In the case of an asset such as an inventory item that generates a receipt in only one accounting period, the standard deviation is zero by definition, since the "stream" is then as tightly bunched as possible. ${ }^{82} \mathrm{On}$

80. Mathematically, $M$ in note 79 supra may be rewritten

where $T=$ total receipts.

$$
M=\left(\sum_{i=1}^{L} i R_{i}\right) / T
$$

81. The formula for the standard deviation (S.D.), which is the central formula of this Note, is

$$
S . D .=\sqrt{\sum_{i}^{L} r_{i}(i-M)^{2}}=\sqrt{r_{1}(1-M)^{2}+r_{2}(2-M)^{2}+\ldots+r_{L}(L-M)^{2}} .
$$

See W. Feller, Introduction to Probability Theory and Its Applications 213 (2d ed. 1957). The mathematical motivation for this formula may be summarized through the following steps:

1. A measure is sought to describe how widely the deferral times are spread around the average deferral time $(M)$.

2. The initial naive idea is to add up the deviations from $M$ as the chosen measure of spreading or dispersion. However, this yields zero because the negative deviations can be shown always to cancel exactly out the positive ones, i.e., $\sum_{i}{ }_{1} r_{1}(i-M)=0$ (this is a corollary of how $M$ is defined).

3. To get rid of negative quantities in the sum, square $(i-M)$ in each term in the sum, exploiting the fact that the square of any number is positive. Thus obtain

$$
i \stackrel{L}{=} r_{i}(i-M)^{2}
$$

4. This formula will always yield a satisfactorily positive result. However, since we have squared a quantity having the dimensions of [TIME], the formula yields a number having the dimensions of [TIME] $]^{2}$, and so (in a spatial analogy) is analogous to [AREA] rather than to [LENGTH]. To convert back into units comparable with $M$ (whose dimensions are those of [TIME]), take the square root, yielding the formula shown.

This fourth step is not required for the particular use to which the S.D. is put in defining "capital asset." Specifically, S.D. $>c$ if and only if $(S . D .)^{2}>c^{2}$, where $c$ is the threshold cutoff of p. 745 infra, so that the present capital asset standard could be stated without taking a square root. However, this slight gain in computational simplicity is outweighed by the lesser interpretability of a standard that proceeds in terms of quantities with dimensions [TIME] ${ }^{2}$, not [TIME]. For numerical illustration of how S.D. is computed, see notes $95 \& 102$ infra.

82. Formally: $r_{i}$ is zero for $i \neq k$, so that all terms in the summation within the S.D. formula are zero except possibly for the $k$ th term. But note that $k=M=$ average deferral time, see note 79 supra, so that the $k$ th term $=r_{k}(k-M)^{2}=0$, whence all terms in the S.D. summation are zero and the statement in the text follows. This works neatly only if one adopts a vantage point in time after the asset has been sold (as contrasted with an ex ante 
the other hand, where receipts are obtained uniformly across the life of the asset, as under a contract stipulating fixed rental payments, the standard deviation is positive and increases in direct proportion to the lifetime of the asset. ${ }^{83}$

A reasonable ${ }^{84}$ "cutoff point," at which the spreading is large enough to qualify the asset for capital asset status, is 1.5 years (six quarters). Such a point would accord capital asset status to all uniform streams having duration longer than 5.2 years, and ordinary income status to shorter uniform streams. ${ }^{85}$ Although any such choice of cutoff is no less arbitrary than many other dividing points in the Code, ${ }^{80}$ the cutoff

viewpoint where there is a positive expected receipt in each future period, depending on the estimated sale probability in that period). To clear up any ambiguity, one may simply follow the familiar tax expedient of adopting the point of view less favorable to the aspiring taxpayer. In the present situation, this will always be the ex post calculation yielding a zero S.D., as opposed to the ex ante calculation yielding a positive $S . D$.

83. Specifically, when receipts are uniformly realized over both past and future lifetimes (constant stream of receipts), one has $r_{i}=1 / L$. Then

and

$$
M=\sum_{i=1}^{L} i r_{i}=\frac{L+1}{2}
$$

using

$$
S . D .=\sqrt{\sum_{i=1}^{L} r_{i}(i-M)^{2}}=\sqrt{\frac{1}{L}\left[\frac{L}{6}(L+1)(2 L+1)-M L(L+1)+M^{2} L\right]},
$$

$$
\sum_{i=1}^{L} i^{2}=\frac{L(L+1)(2 L+1)}{6},
$$

which may be proved by mathematical induction. Substituting $M=(L+1) / 2$ in the S.D. expression obtained and simplifying, the $S . D$. is shown to be

$$
S . D .=\sqrt{\frac{L^{2}-1}{12}} \cong .29 L \text { for large } L
$$

and is thus very nearly proportional to the lifetime with an error of less than one percent for $L>10$.

84. Alternatively, one might use the S.D. measure as the basis for a sliding scale of tax rates, with the extent of favored treatment increasing as a continuous function of the spreading of receipts. The approach in the text is recommended largely for its conformability to the existing structure of capital gains treatment, and the sliding scale approach merits further exploration.

An alternative strategy to selecting the cutoff would focus on conservation of revenue, and choose its value so as most nearly to match total (capital gains and ordinary income) revenue to that collected under the existing law.

85. This result may be derived, employing the formula of note 83 supra with a quarterly accounting period, by setting

$$
\sqrt{\frac{L^{2}-1}{12}}=6 \text { (quarters), }
$$

whence $L^{2}=(36 \times 12)+1=433, L=20.8$ quarters or 5.2 years. Longer uniform streams will exceed the imposed cutoff, shorter ones will fall short of it.

86. E.g., I.R.C. $\$ 368$ (c) (80\% control test); B. BITTKER \& J. Eustice, FEDERAL INCOME Taxation of CoRrorations and Shareholders 3-29 (3d ed. 1971) (favoring clarity of $80 \%$ control test of I.R.C. $\$ 368(c))$. 
proposed is consistent with the notion that sixty months (five years) is a "short" life for purposes of the fast amortization provisions of the Code ${ }^{87}$ and that ten years is a "long" period for reversionary interest purposes in the Clifford area $^{88}$ and various other Code provisions. ${ }^{80}$

\section{Remaining Requirements Taken from Current Law}

In a contract termination payment or section 1221(1) case, long-term capital gain status is then to be accorded to gain on any disposition of a capital asset, as defined by applying the spreading of receipts criterion, where (1) the one-year holding period requirement of sections 1222 and 1223 is satisfied and (2) the sale or exchange requirement under section 1222 is also met.

Retention of the existing law's holding period requirement results from the uncertainties of prospectively valuing the future stream of receipts. ${ }^{90}$ Because the proposed capital asset standard depends in part on such valuation, the holding period assumes a stabilizing purpose, for it guarantees that at least four quarters of the stream will consist of data rather than projections.

The evolution of the sale or exchange doctrine has seen the law moving slowly toward a "spreading of receipts" idea that complements the present proposal. Specifically, if the sale or exchange doctrine is applied to bar the capital gains preference when consideration is spread out in time, as in the "bootstrap acquisition" pledge of a part of the future income of an acquired business, ${ }^{91}$ the doctrine may operate as a converse to the proposed capital asset test: capital gains treatment is to be denied if either the receipts attributable to the asset are heavily bunched in time (violation of the capital asset norm) or the considera-

87. E.g., I.R.C. $\$ 167(k)$ (60-month straightline depreciation of expenditures to rehabilitate low income rental housing); $i d$. $\$ 169$ (60-month amortization of pollution control facilities); id. $\$ 184$ (60-month amortization of certain qualified railroad rolling stock). See also B. BitTKer \& L. Stone, supra note $\mathrm{I}$, at 325 (discussing other, analogous sections).

88. See I.R.C. $\$ 673$ (a) (10-year limit beyond which provision for reversion to grantor will not trigger tax liability to grantor).

89. E.g., I.R.C. $\$ 302(c)(2)$ (10-year rule for determining termination of interest under I.R.C. $\$ 302(b)(3))$.

90. Cf. McClung, The Distribution of Capital Gain on Corporate Shares by Holding Time, 48 REv. Econ. \& Statistrcs 40 (1966) (optimal holding period length is empirical queston; need for data on question).

91. Compare Commissioner v. Brown, 380 U.S. 563 (1965) (capital gains characterization in bootstrap acquisitions, i.e., acquisitions of one business by another where all or part of the consideration is pledge of part of future earnings stream of acquired business) with I.R.C. $\$ 514$ (reversing Brown in part) (denying capital gains treatment on a formerly important class of charitable bootstraps); Commissioner v. Brown, 380 U.S. at 581 (Goldberg, J., dissenting) (criticizing Brown) and M. ChIRELsTeIN, supra note 19, at 294-95 (similar). But see Hall, The Clay Brown Case and Related Problems, 1966 S. CAL. TAX INST. 337 (highly sympathetic view of opinion by counsel for taxpayer who won case). 
tion received on disposition is widely dispersed in time (violation of the sale or exchange norm). ${ }^{92}$ In general, the existing law on the sale or exchange requirement is very complex and this Note merely incorporates it by reference. ${ }^{93}$

\section{B. Application of the New Test to Leading Cases}

Examples taken from leading cases construing the capital gains definition illustrate the new capital asset test. All examples apply the spreading of receipts test using the 1.5 year (six quarter) cutoff previously recommended.

Example 1: Payment for cancellation of fixed-rental lease contract. Following the basic facts of $\mathrm{Hort}^{94}$ assume that the asset being disposed of (by cancellation of contract for lump-sum consideration) is a fixed-term building lease. The lease contract provides an annual rental of $\$ 25,000$ and covers the years $1932-1947$, with cancellation occurring in 1933.

Application of the spreading of receipts formula to a stream of uniform rental payments lasting sixty quarters yields a standard deviation value of 4.32 years. ${ }^{95}$ Since 4.32 years exceeds the threshold of 1.5 years, the contract right to receive rental payments is a capital asset under the formula. ${ }^{96}$ Capital gains treatment should thus apply to

92. For a similar statement of what the sale or exchange doctrine should accomplish, see M. Chirelstein, supra note 19 , at 295.

93. For a partially dated review of the law, see Note, supra note 36, at 701-04. As with so much law in the capital gains field, the roots of the sale or exchange doctrine are in unrelated areas of taxation, notably the "open transactions" doctrine of Burnet v. Logan, 283 U.S. 404 (1931) (no current tax liability where asset received is found to be incapable of present valuation). The critics have by and large been no more charitable to the sale or exchange doctrine than they have been to the capital asset concept. See, e.g., Miller, supra note 1, at 885; Surrey, supra note 1, at 1007 .

94. Hort v. Commissioner, 313 U.S. 28, 29 (1941).

95. I.e., using the formula developed in note 83 supra, $S . D .=\sqrt{\frac{60^{2}-1}{12}}=17.3$ quarters $=4.32$ years. In any case such as this where the stream of receipts is uniform, the ab. solute magnitude of the receipts obtained in each period does not influence the tax result. In mathematical terms, this invariance follows from the fact that S.D. is zero-order homogencous as a function of $R=\left(R_{1}, R_{2}, \ldots, R_{L}\right)$ (notation following note 70 supra). Many contract cases will stipulate a uniform receipt, though uniformity cannot of course be expected in general (which is the reason why the present theory requires the more general S.D. formula of note 81 supra).

96. Two complications should be noted. First, a peculiarity of the Hort facts involved finalization in 1927 of the contract governing the 1932-1947 lease. Hort v. Commissioner, 313 U.S. 28, 29 (1941). Thus there appears to be ambiguity as to whether the S.D. measure should be applied to a 15 -year stream, see note 95 supra, or to a 20-year stream (1927-1947) whose first five years produced zero receipts to lessor. But the two approaches, although seemingly different, in fact each lead to the same S.D. of 4.32 years. To see this equivalence mathematically, call the 15-year stream Stream I and the 20-year stream Stream II. 
lessor's receipt of the lump-sum consideration, a result opposite to that arrived at by the Supreme Court.97

Example 2: Consideration received for carved-out oil payment rights. In Commissioner v. P.G. Lake, Inc., ${ }^{98}$ a corporation engaged in extraction of oil assigned an oil payment right to a third party in consideration of the cancellation of a debt owed by the corporation to the third party. Consider initially the simplified situation based on the Lake facts where the debt is $\$ 600,000$ and the assigned right gives the third party the right to receive $\$ 200,000$ in each of the three years following assignment. Application of the spreading of receipts formula to the "asset" transferred, conceived as a three-year stream of $\$ 200,000$ per year (with a yearly accounting period), yields a standard deviation of .82 years, less than the 1.5 -year cutoff. Thus capital gains treatment should be denied to the corporation when it receives cancellation of indebtedness income at the time of the assignment. This result concurs with that reached by the Supreme Court.

In contrast to the "substitute for ordinary income" doctrine applied in the actual Lake case, ${ }^{99}$ however, the present result turns strictly on the comparatively short-term character of the payment right assigned. If the assigned right had a cash value of $\$ 60,000$ per year over the next

For Stream I, $M=30.5$ quarters and for Stream II, $M=50.5$ quarters, corresponding to a five-year longer waiting time. The S.D. for Stream I,

$$
S . D .=\sqrt{\sum_{i=1}^{60} \frac{1}{60}(i-30.5)^{2}}=\sqrt{\sum_{i=21}^{80} \frac{1}{60}(i-50.5)^{2}}
$$

The second way of writing the sum is readily seen to coincide with the S.D. of Stream II, relying on the fact that for this stream, $r_{i}=0$ for $i=1,2, \ldots, 20$ and $r_{i}=1 / 60$ for $i=$ $21,22, \ldots, 80$.

Second, the way in which the S.D. formula is applied in the text takes no account of the motives that may underlie lessor's readiness to accept cancellation. If, for example, the lessor readily accepts cancellation because of lessee's imminent insolvency, it is reasonable to discount that part of the rental stream not yet paid to the taxpayer-landlord, and the spreading of the income stream in the landlord's hands will diminish accordingly. The taxpayer will therefore argue that cancellation of the lease has not taken place on account of insolvency concerns, and the Service will be equally ready to argue that this is in fact the dominant motive. In this situation, which requires a determination of the financial circumstances of a party (the lessee) not privy to the tax transaction, one is tempted to reverse the normal evidentiary presumption placing burden of proof on taxpayer in federal tax transactions. For precedent in doing this under Tax Court Rules, sce $R$. Holzman, The Taxpayer's Problem of Proof 5-6 (1972) (situations where burden may be on either party depending on the facts); id. at $6-8$ (situations where burden is on the Secretary).

97. Hort v. Commissioner, 313 U.S. 28, 31 (1941). For a critique of the Hort approach, see pp. 732-33 supra.

98. 356 U.S. 260 (1958). The statutory background has altered as a result of Lake: I.R.C. $\$ 636$ now requires that most carved-out production payments of the Lake type be treated as mortgage loans. See Collie \& Linden, The Tax Reform Act of 1969 and Domestic Oil and Gas, 21 Sw. Legal Foundation Inst. ON OIL \& Gas L. \& Tax. 419, 425-32 (1970).

99. 356 U.S. at 265. 
ten years, in consideration for the cancellation of the debt, the effect would be indiscernible from disposition of any other type of long-term investment, and capital gains treatment should apply to the corporation. ${ }^{100}$

The formula actually used in Lake to govern the terms of the assignment was somewhat more complicated than uniform repayment. Specifically, the substance of the Lake income assignment was to pay off a portion of the remaining debt in each year until full repayment had been achieved, but in no year was the amount repaid to exceed twentyfive percent of the company's working interest for that year. ${ }^{101}$ If the proceeds varied, the yearly repayments would likewise fluctuate in the same proportion. For example, if the twenty-five percent ceiling permitted repayment of $\$ 300,000$ in year one (corresponding to $\$ 1,200,000$ in total receipts from the working interest for that year), $\$ 150,000$ in year two (total receipts of $\$ 600,000$ ), and $\$ 150,000$ in year three, the lifetime of the assignment would still be three years, but the annual receipts would fluctuate; the standard deviation of waiting times would now be .83 years (annual accounting period). ${ }^{102}$ The spreading of receipts.threshold would still not be met, and there would be no change in the tax result.

Example 3: Receipts obtained from sale of commodity futures. Following Corn Products, ${ }^{103}$ assume that a taxpayer sells future interests in commodities that are used as raw materials in the taxpayer's business, thus attempting to maintain a balanced long-term position in a volatile supply market. ${ }^{104}$ Specifically, the Corn Products Company would normally purchase futures contracts in the fall, take delivery on such contracts as it found necessary to its manufacturing operations, and sell the remainder in early summer if no shortage appeared imminent.

In applying the spreading of receipts formula, it is important that all futures contracts called for delivery in several months. In other words, they were short-term contracts bought and sold on speculation

100. Indirectly, the economic effect would be to reward the firm for working a longterm extraction interest. See pp. 738-40 supra (policy discussion).

101. 356 U.S. at 262. It appears that by the time the Lake litigation had reached the Supreme Court, full repayment had been completed. The terms of the assignment also provided for three percent interest payments on the outstanding debt principal, which are ignored for simplicity in the present calculation.

102. Dropping 000s (which are immaterial anyway, see note 95 supra), the stream is $(300,150,150)$, yielding $M=(1 / 2 \times 1)+(1 / 4 \times 2)+(1 / 4 \times 3)=1.75$ years, S.D. $=$ $\sqrt{1 / 2(1-1.75)^{2}+1 / 4(2-1.75)^{2}+1 / 4(3-1.75)^{2}}=.83$ years (yearly periods of account).

103. Corn Prods. Refining Co. v. Commissioner, 350 U.S. 46 (1955).

104. On the economic background of transactions of the Corn Products type, see A. Goss \& B. Yamey, The Economics of Futures Trading (1976); Houthakker, The Scope and Limits of Futures Trading, in The Allocation of Economic Resources (1959). 
about the yield of the harvest in the year following purchase. ${ }^{105}$ Thus, if the corporation elected to sell, sales of futures bought at a given time could not have extended over much more than a year, implying a standard deviation of sales receipts of two quarters at most, much less than the 1.5-year threshold proposed for capital asset treatment. ${ }^{100}$ The proposed standard would therefore deny capital gains treatment in the Corn Products fact situation, regardless of the details of the transactions, because it is not possible to make a "long" asset out of a nearterm future. ${ }^{107}$ This short-term character is typical of most agricultural futures, where the contracts involved normally call for delivery in one year to eighteen months. ${ }^{108}$

Example 4: Losses from bankruptcy of a corporate subsidiary. Following the facts of W.W. Windle Co. v. Commissioner, ${ }^{109}$ suppose that a corporation sets up a subsidiary to act as a "captive customer" for its products and also for possible gain through asset appreciation. After a number of years of unsuccessful operations, the subsidiary is liquidated. Is the parent's loss on the subsidiary's common stock to be treated as a capital loss (as would normally be the case on stock losses), or an ordinary loss deduction under section 165(a) (if the stock is conceived merely as a proxy for the interest of the parent company in the subsidiary's operating assets) ?110 $^{110}$

105. 350 U.S. 46, $48-49$ (1955). For a more detailed statement of facts, see Corn Prods. Refining Co. v. Commissioner, 16 T.C. 395, 396 (1951) (contracts involved stipulated for delivery in 11 months or less).

106. For a stream whose length is known it can be shown that the greatest possible $S . D$. arises when half the receipts are in the first period and half in the last. For such a stream, if the length is $L$,

$$
\begin{aligned}
& M=1 / 2(L+1) \\
& \text { S.D. }=\sqrt{1 / 2(1-1 / 2[L+1])^{2}+1 / 2(L-1 / 2[L+1])^{2}}=(L-1) / 2,
\end{aligned}
$$

so that in the case of a stream lasting $L=4$ quarters, the greatest possible $S . D$. is 1.5 quarters.

107. A different result could ensue in cases where a set of extremely long-term futures contracts are purchased in a batch and then sold piecemeal over a long period, producing a long-term stream of receipts and mimicking the spreading of receipts that is the hallmark of capital assets under the proposed standard. See Yamey, Short Hedging and Long Hedging in Futures Markets: Symmetry and Asymmetry, 14 J.L. \& Econ. 413 (1971). A closely analogous situation is presented by oil in place that is purchased for extraction and sale. Such a depletable resource is a hybrid between "inventory" and a "capital asset." See Freeman, Percentage Depletion for Oil-A Policy Issue, 30 IND. L.J. 399, 403 n.II (1955) (finding greater similarity to inventory).

108. See T. Hieronymus, Economics of Futures Trading for Commercial and PerSONAL Profit 38 (1971) (futures contracts generally extend forward one year, though silver futures are typically 15 months); S. Kroll \& I. Shisko, The Commodity Furures Market GuIDE 11 (1973) (commodity futures contracts begin trading with maximum life varying from nine to eighteen months).

109. 65 T.C. 694 (1976), appeal dismissed, 550 F.2d 43 (Ist Cir. 1977).

110. Applying Corn Products, the Tax Court held for the Commissioner "on the 
To apply the spreading of receipts formula in this type of case, it seems most realistic to examine directly the dispersion of the subsidiary's earnings stream, or (when the parent is not a full owner) the dispersion of that part of the subsidiary's earnings that are attributable to the parent on a pro rata basis through stock ownership. ${ }^{111}$ In the case of the Windle subsidiary, which was seventy-two percent owned by its parent-taxpayer, ${ }^{112}$ the eight years of operating life from 1962 through 1969 showed only two years (1965 and 1966) with a positive profit. 113 Hence the appropriate stream whose spreading is to be computed is a stream consisting of thirty-two quarters, eight of which are presumptively positive and the remainder of which are zero. ${ }^{114}$ Assuming that the profits were realized evenly across the four quarters in the two tax years showing a balance-sheet profit, the standard deviation is .57 years, falling short of the 1.5 year threshold and indicating ordinary loss treatment. If comparable profit levels had also been realized in 1963-64 and 1967-68, however, sufficient spreading would have been present to hold the taxpayer to capital loss on the stock (standard deviation of 1.73 years). In the situation where no profits at all are realized, creating a zero profit stream, capital loss treatment should apply, since the spreading measure is then not mathematically defined and hence gives no reason to depart from the conventional position that stock is a capital asset. $^{115}$

ground that, while petitioner's principal motive was to acquire a captive customer, it had a substantial subsidiary investment motive, which prevented it from being entitled to an ordinary loss." Id. at 704 (emphasis added). Just how the taxpayer could have shown that its "investment" motive was insubstantial is far from clear.

111. If, for example, there is an $80 \%$ ownership interest over all periods, the stream to which $S . D$. is to be applied is $.8 R_{1}, .8 R_{2}, \ldots .8 R_{L}$, where $R_{i}=$ income of the controlled corporation in period $i$. Observe that this gives the same $S D$. as in the case of $100 \%$ ownership, since the S.D. does not depend on the absolute magnitude of the stream, see note 95 supra. Thus the only way in which S.D. could be affected by the ownership proportion is if this proportion varies over the history of the stream, in which case the $S . D$. is applied to the stream $\left(f_{1} \times R_{1}\right),\left(f_{2} \times R_{2}\right), \ldots,\left(f_{L} \times R_{L}\right)$ where $f_{\mathfrak{i}}$ is the ownership proportion applicable to period $i$.

112. 65 T.C. at 696.

113. Id. at 698 .

114. This assumes, of course, that profits are realized uniformly across quarters within each tax year.

115. Specifically, one has $T=0$, whence $r_{i}=0 / 0$ and is arithmetically undefined in all quarters. Thus the S.D. measure, which is defined using the $r_{t}$ in the formula of note 81 supra, does not exist mathematically in this case.

It is easy to see that S.D. will be undefined only in this case of a strictly zero income stream, since in $r_{t}=R_{t} / T$ the denominator $(T)$ is zero only when there are no receipts in any period. If total receipts are very small, the S.D. measure, although no longer mathematically undefined, will be highly sensitive to small errors in measurement and disagreements concerning valuation. However, for most practical applications where sums are sufficiently substantial to be litigated, this type of difficulty will not arise. 
IV. Advantages of the Spreading of Receipts Standard

The proposed mechanical standard should yield advantages over current law. Conceptually, the formula yields a coherent, consistent rule justifiable by reference to a leading economic rationale for the capital gains preference. Practically, the formula should be workable and, moreover, will facilitate planning and reduce litigation in a confused area of tax law.

\section{A. Economic Justification of the New Standard}

Insofar as the encouragement of long-term investments may be taken as the direct objective of the capital gains system, ${ }^{116}$ the spreading of receipts test is an appropriate and consistent legal vehicle for implementation of that policy. There is no uniquely correct means of defining the concept of "economic life," but the approach developed through the spreading of receipts formula is supported both by statistical tradition ${ }^{117}$ and by the results it yields in the cases examined. ${ }^{118}$ The simpler measure of economic "life," namely average time to realization of returns, ${ }^{119}$ is in fact not in keeping with the economic policies motivating capital gains treatment. Specifically, defining a "capital asset" as an asset for which the average deferral time for receipts exceeds some specified cutoff would encourage holding potentially productive assets idle in the hope of windfall gain. ${ }^{120}$ Indeed, were such a standard to be adopted rather than the present one, any asset

116. See pp. 738-40 supra.

117. See, e.g., 1 M. Kendall \& A. Stuart, The Advanced Theory of Statistics 41.54 (3d ed. 1969). But see Boorman \& Arabie, Structural Measures and the Method of Sorting, in 1 Multidimensional Scaling: Theory and Applications in the Behavioral Sciences 225 (R. Shepard, A. Romney \& S. Nerlove eds. 1972) (alternative formulas derived from lattice theory); Hopewell \& Kaufman, Bond Price Volatility and Term to Maturity: $A$ Generalized Respecification, 63 AM. EcoN. REV. 749 (1973) (alternative financial length measure, "duration," applied to analysis of bond prices).

118. A brief tabular summary may be useful here:

\begin{tabular}{lcc}
\multicolumn{1}{c}{ Case } & SPREADING OF \\
REcEIPTS TEST & Historical OUTCOME \\
Ex. 1. Hort & KG & OI \\
Ex. 2. Lake & OI & OI \\
Ex. 3. Corn Products & OI & OI \\
Ex. 4. Windle & OL & KL
\end{tabular}

Here $\mathrm{KG}=$ capital gain, $\mathrm{KL}=$ capital loss, $\mathrm{OI}=$ ordinary income, $\mathrm{OL}=$ ordinary loss.

119. See pp. 743-44 supra. Mathematically, this average deferral time is $M$ in note 79 supra. In the case where there is only one receipt, $M$ is just the waiting time to realization of this single receipt.

120. From a macroeconomic standpoint, the effect of using $M$, rather than S.D., as the basis for a capital asset standard would be the systematic encouragement of excess capacity. See, e.g., Kaldor, The Theory of Excess Capacity, 2 Economica (n.s.) 33 (1935). The economic undesirability of such encouragement has been recognized since the time of Keynes. 
could in principle be converted to a "capital asset" merely by holding it long enough. Following through the abstract logic, capital gains treatment would not only be justified for the amateur land speculator-long the bette noire of Code critics ${ }^{121}$-but also to inventory or inventory-like items merely because those items were particularly slow in turning over.

A second major aspect of the proposed standard may also be justified by economic considerations. That is, the relevant "length" of an investment must be evaluated from the viewpoint of the seller, who pays the taxes on the sale and who is the "long investor" that ordinary income treatment would lock-in. There are two natural points at which to commence the income stream that is to be entered into the spreading formula: (1) the time at which the asset first entered the seller's hands; (2) the time of the sale now being taxed (so that "length" is now a guess as to the expected future lifetime measured from the time of sale). In rejecting the second alternative and embracing the first, the proposed test is responsive to the potential deterrent effects of anticipated lock-in as well as to lock-in itself. ${ }^{122}$ Moreover, choice of the second alternative would have untoward effects. Specifically, under this alternative there would exist a point during a tenure of ownership at which a "capital asset" would be abruptly transformed into one whose disposition generates ordinary income, since the future life would have become too short to sustain the degree of spreading necessary for capital asset status. ${ }^{123}$ This "switch over" would create an unwarranted tax incentive for owners to dispose of assets in the middle of their productive lifetimes. The first alternative does not in general imply such a "switch" and thus provides a better basis for defining the stream of receipts. ${ }^{124}$

\section{B. Practical Aspects of the New Standard}

The present theory should be seen as extending the tradition of mechanical standards that is already well-established in other Code

121. See, e.g., Miller, supra note 1, at 843 ("Much criticism has been directed against the resultant paradox that a man's 'sideline' speculations are taxed more leniently than the income from his principal occupation.")

122. But cf. Ali, Draft of a Study of Definitional Problems in Capital Gain TaxaTIoN 26 (1960) (proposing that residual areas of capital asset definition be governed by denying capital gains treatment to "limited duration assets," i.e., those that will not have substantial value for more than fixed number of years following taxable transaction).

123. Of course, any holding period creates a similarly arbitrary transition in the opposite direction, making the taxpayer suddenly eligible for long-term capital gains preference when the holding period is met. However, as stated previously, see p. 746 supra, retention of the holding period is justified for stability reasons.

124. Purists may note that the formally correct way of defining this stream would be to seek to recreate the prospective stream of returns to the asset as that stream would have appeared at the point when the asset now being sold was first acquired. However, since the historical stream $R_{1}, R_{2} \ldots R_{n}$ is the best proxy for this expectation in most cases, such a retroactive projection seems a needless attempt at precision. 
areas. The advantages of mechanical, brightline tests are well known: they tend to be uniform in application, yielding a high degree of consistency across cases and courts (and thereby reducing litigation), and often allow the spotting of naive avoidance attempts more easily than standards couched in softer terms. ${ }^{125} \mathrm{Mechanical}$ standards also facilitate legal planning, ${ }^{126}$ a consideration particularly important in the capital gains area, where major economic dislocation can result from a successful Service challenge to a claimed capital gain that is largely an illusory gain because of inflation. ${ }^{12 \pi}$ The main disadvantages of brightline tests are equally well known: such tests generate inequitable results in individual cases and may encourage sophisticated avoidance attempts. ${ }^{128}$ However, it should be possible to limit these disadvantages by restrained judicial intervention, principally in the form of a "business purpose" doctrine that would invalidate contractual devices that create an artificial spreading of receipts in order to receive capital gains treatment. ${ }^{129}$ Such a pattern-limited judicial control exerted on a well-

125. On the effectiveness of brightline formulas in cutting off litigation, contrast the gloomy remarks of Judge Hand on the burgeoning case load that followed in the wake of Helvering v. Clifford, 309 U.S. 331 (1940), see Kohnstamm v. Pedrick, 153 F.2d 506, 510 (2d Cir. 1945), with the comparatively litigation-free later history of the area once the Clifford Regulations had been put out by Treasury, see note 69 supra.

126. See H. Bierman, Decision Making and Planning for the Corporate Treasurer (1977) (emphasizing tax planning in rational corporate financing).

127. A useful cautionary illustration as to what may occur when tax distinctions become too diffuse is provided by the recent history of the debt/equity classification issue. Caplin, The Caloric Count of a Thin Incorporation, 17 N.Y.U. TAX INsT. I71 (1959), re. printed in 43 MARQ. L. REv. 31 (1959), reviews the high-water mark of an attempted brightline formula approach in this area. Subsequent developments have receded back in the direction of holistic ("all the circumstances") solutions. So murky have the lines become that planning has become a nightmare, see Dixon, The Interest-Dividend Syndrome: What Are the Criteria Now?, 24 N.Y.U. TAX INST. 1267 (1966), and commentators have audibly wondered "whether the realism obtained is worth this price." 2 SURREY $\&$ WARREN, supra note 16 , at 213.

128. A less commonly articulated, though nontrivial, problem with brightline standards generally is that mechanical formulas, once established at a statutory level in the Internal Revenue Code, are typically hard to change, except in the direction of still more elaborate formulas. An example is the elaboration of I.R.C. $\$ 382$, providing for a class of special limitations on net operating loss carryovers, that took place under the Tax Reform Act of 1976. This viscosity problem is a significant part of the considerations that underpin the present recommendation to make the new spreading test embodied initially in the Regulations, rather than the Code itself. See p. 741 supra.

129. There is, however, one part of this problem that mandates statutory resolution. Specifically, as far as possible taxpayer election of the I.R.C. $\S 453$ installment basis is concerned, it seems sensible to treat election of this basis as precluding capital gains treatment of any of the installment payments received, thus blocking any possible double tax advantage from exercising the election. This provision would reverse the existing law, which creates no bar to making the capital gain preference fully available to installment sellers. See M. Chiresstern, supra note 19, at 259 , 294. The installment method as implemented in the existing statute is in any case itself a major target for long-overdue reform. See Ginsburg, Taxing the Sale for Future Payment: A Proposal for Structural Reform, 25 S. Cal. Tax INST. 1 (1975), reprinted in 30 TaX L. REv. 471 (1975). 
developed mechanical underpinning in the Code and Regulations-is one that has been highly successful (and is becoming increasingly common) in many Code areas, especially the corporate tax field. ${ }^{130}$ In the area of capital asset definition, this pattern should replace the far broader and vaguer judicial doctrines of the type exemplified by Hort and Corn Products. ${ }^{131}$

Within the general framework of mechanical tests in the Code, the spreading of receipts formula raises two specific problems. A major characteristic of the standard is that it involves mathematics. Even in taxation, lawyers remain uncomfortable with mathematical formulas, and a significant class of objections to the present proposal therefore concerns the mathematical complexity of the legal standard it would create. ${ }^{132}$ In fact, however, numerous current sections of the Code and

130. See Clark, The Morphogenesis of Subchapter G: An Essay in Statutory Evolution and Reform, 87 YALE L.J. 90, 96 (1977) (review of forces favoring increased use of mechanical statutory standards in the Code's treatment of corporations and shareholders). Among the many Subchapter $\mathbf{C}$ areas to undergo an apparently successful evolutionary progression from general judicial rules to statutory mechanizations are: (1) the stock dividends area, where the principle of Eisner v. Macomber, 252 U.S. 189 (1920), found eventual mechanical expression in I.R.C. $\$ 305$; (2) the security bailout area, where the principle of Bazley v. Commissioner, 331 U.S. 737 (1947), was made into a mechanical rule in I.R.C. $\$ \$ 354(a)(2), 356(d)$; and (3) the preferred stock bailout area, where taxpayers victory in Chamberlin v. Commissioner, 207 F.2d 462 (6th Cir. 1953), was reversed by statute in I.R.C. $\$ 306$. Most of these mechanizations retain some slack for exercise of judicial and administrative discretion, e.g., I.R.C. $\$ 306(\mathrm{~b})(4)$ (exception to ordinary income treatment for "transactions not in avoidance").

131. In some tax areas, mere statutory embodiment of judicial rules has done little to eliminate vagueness, e.g., the "device" language of I.R.C. $\$ 355(\mathrm{a})(\mathrm{I})(\mathrm{B})$ (governing tax-free status of divisive reorganizations) embodying the rule of Gregory v. Helvering, 293 U.S. 465 (1935). Even though the rule in this case has been elevated to statute, little content has been added and the same kind of judgmental guesswork seems required for application. This is paradigmatic of the type of tax statute that the present capital gains standard secks to avoid. For a critique of Gregory and its progeny, see Chirelstein, supra note 25, at 442-59.

132. On the general problem of complexity in the tax law, for which this concern could be phrased as a special instance, see Kingson, The Deep Structure of Taxation: Dividend Distributions, 85 YALE L.J. 861 (1976); Ginsburg, Letter to the Editors, 86 YALE L.J. 798 (1977); Kingson, Author's Reply, 86 YALE L.J. 806 (1977); Roberts, Friedman, Ginsburg, Loothen, Lubrick, Young \& Zeitlin, $A$ Report on Complexity and the Income Tax, 27 Tax L. Rev. 325 (1972) (New York State Bar Ass'n, Tax Section, Comm. on Tax Policy). But see Surrey, supra note 1, at 985 ("The fact that our tax law is complex does not necessarily mean that it is poor law.') $A$ deeper level of objection surrounds possible conflicts between mathematical procedures and more fundamental values. See Tribe, Trial by Mathematics: Precision and Ritual in the Legal Process, 84 HARv. L. Rev. 1329 (1971) (conflicts with other values that use of mathematics engenders in conduct of civil and criminal trials); Finkelstein \& Fairlcy, A Comment on "Trial by Mathematics," 84 HaRv. L. REv. 1801 (1971) (subsequent debate over Tribe's position); Tribe, A Further Critique of Mathematical Proof, 84 Harv. L. Rev. 1810 (1971) (same). The abstract issue in the background is, of course, the traditional cultural gap between the mathematical culture and the legal culture. See G. Hardy, A Mathematician's Apology (1940); C. Snow, The Two Cultures: ANd a SEcond Look (2d ed. 1964). There is an interesting converse to this cultural issue. If $S . D$. is indeed the basis for the legal standard that the capital gains 
Regulations invoke at least as much purely arithmetical complexity, either expressly ${ }^{133}$ or by implication, ${ }^{134}$ as does the proposed capital gains test. This is especially true in areas on the boundary between law and actuarial science such as calculations of remainder interests in trusts for the purposes of estate taxation. ${ }^{135}$ The mathematically distinctive feature of the present test is that it relies on a statistical standard deviation or variance, whereas most of the established formulas covering remainder or reversionary interests involve mean values only. ${ }^{136} \mathrm{How}$ ever, the notion of a variance calculation is percolating into tax law through the growing role of portfolio theory in corporate and securities law. ${ }^{137}$ Thus the present proposal should create only a minimal discontinuity with current legal ideas.

Second, there should also be a natural concern that mischaracterizations of capital asset status may occur, in the sense that the actual spreading of the stream of receipts as the future unfolds may differ

field has long needed, it is not a standard that seems likely to emerge as the outcome of a long history of judicial accretion. As a result, it is not perhaps surprising that the common law development of the capital gains definition has been fairly unsuccessful, by contrast to certain other areas where problems are better suited to common law attack. See Brown, The Growing "Common Law" of Taxation, 34 S. CAL. L. REv. 235 (1961).

133. E.g., I.R.C. $\$ 341$ (massively detailed provision defining "collapsible corporations" for tax purposes). It is quite interesting that most of the litigation seems to have focused around the inherently vague criteria of "purpose" with which I.R.C. $\$ 341$ (a) is rife, not around the horrendously complex, though mechanical, verbal formula of I.R.C. $\$ 341$ (c). See [1977] 4 FED. TAXEs (P.H.) IT 17,783-93; Pelletier, Shareholder Intent and Congressional Purpose in the Collapsible Corporation Morass, 20 TAx L. Rev. 699, 730 (1965) (objective standards of $\$ \S 341(\mathrm{e})-(\mathrm{f})$ are amendments in reaction to muddiness of "intent" standard). But see 2 SURREY \& WARREN, supra note 16, at 553 ("aura of unreality" about $\$ 341$ (e)); Goldstein, Section 3f1(d) and (e)-A Journey into Never-Never Land, 10 VILL. L. REV. 215 (1965).

134. See M. DAvid, supra note 6, at 233-36 (mathematical translation of I.R.C. $\$ 1231$, covering property used in taxpayer's business and involuntary conversions). By most measures of computational complexity, the mathematical formula that is derived for $\S 1231$ treatment is more complex than the S.D. formula of note 81 supra.

135. See, e.g., Treas. Reg. $\$ 20.2031-10$, T.D. 6296, 23 FED. REc. 4529 (1958), amended T.D. 7077, 35 FED. REG. 18461 (1970) (valuation rules for annuities, life estates, remainders, and reversions). See also Treas. Reg. $\S 20.2013-6$, T.D. 6296, 23 FED. REg. 4529 (1958) (numerical examples of gift tax credit against estate tax).

136. Thus, for example, an actuarial lifetime is mathematically a mean value across alternative future life trajectories. See N. KeYfitz, INTroduction to the Mathematics of Population 24 (1968). But see Fed. Taxes Est. \& Gifr (P-H) $\mathbb{1}$ 126,703 (Supplemental Instructions for Form 706) (July 17, 1974) ("The problems in Part II [relating to interrelated marital and charitable deductions] must be algebraically expressed with quadratic or higher order equations .... .") Use of an iterative method of solution is proposed, id at if 126,682-M.

137. See V. Brudney \& M. Chirerstein, supra note 22, at 984-1007. The basic twoparameter (mean, variance) model is due to Markowitz. See H. Markowitz, Portfolio SELECTION (1959); Rubinstein, A Mean-Variance Synthesis of Corporate Financial Theory, 28 J. Finance 167 (1973). In a pattern typical of the intellectual history of the law, legal acceptance of these developments has been slow: the first major paper of Markowitz, Portfolio Selection, $7 \mathrm{~J}$. Finance 77 (1952), is separated by almost a generation from the first major legal casebook to cover the mean-variance model in any depth, namely the Brudney-Chirelstein casebook, published in 1972. 
radically from the projected spreading at a given time. As a technical response to this problem, a "throwback rule" principle ${ }^{138}$ may be introduced to correct inaccurate projections. For example, if a pessimistic projection were made at the time of sale of an asset, mandating ordinary income treatment, in some cases the asset might turn out to be still in prime working condition years later, retroactively justifying capital gains on the sale. Then the throwback rule would allow the selling taxpayer to file for a return of the excess tax payment. By symmetry, of course, the taxpayer might be held liable for back taxes if the mischaracterization went the other way (what appears as a capital asset on sale is later determined by the Service to have to have the characteristics of an ordinary income asset). ${ }^{139}$ Such an adjustment procedure should be practicable, since it would only be worth pursuing in cases of highly substantial amounts, where time and trouble are likely to have been taken originally in order to ensure as accurate a financial projection as possible. To make the adjustment scheme not excessively open ended, a definite elapsed time-for example, three years-following realization should be fixed after which new data would not alter the original tax characterization.

\section{Concluding Appraisal}

If a longstanding veil of unnecessary legal complexity can be stripped away from the area of capital gains classification, a half-century of expensive litigation can end and the efforts of lawyers and judges can be directed to more useful pursuits. In seeking to balance the merits of the present proposal against its possible drawbacks, two summary propositions may be advanced. First, it is contended that the advantages gained through the consistency of a brightline approach, notably decreased litigation and greater facility in planning, outweigh any disadvantages that may flow from the apparent complexity of the mechanical standard.140 This judgment takes account both of the failure of existing

138. As provided under I.R.C. $\$ \S 665 \cdot 669$, the general intent of the throwback rules is as a kind of averaging device for income from accumulation trusts. For an overview of the current law, which was revised under the Tax Reform Act of 1969, see Committee on Taxation of Trust Income, The Trust Throwback Rules of the Tax Reform Act, reprinted in 5 Real Property, Probate \& Trust J. 171 (1970); Stevens, Accumulation Trusts and the Throwback Rules, 49 TAXEs 876 (1971). See also M. Chirelstein, supra note 19, at 179 (use of throwback principle to extend tax credit to beneficiary where income tax owing has previously been paid by trust).

139. Equity, as well as efficiency in collection, would suggest that the taxpayer who had initially underpaid should be permitted to pay his outstanding tax over some stipuIated grace period in order to prevent a liquidity crisis.

140. The overriding concern motivating this assessment is the heavy litigation load that has long troubled the capital asset definition field, and particularly the two areas (contract terminations and $\S 1221(1)$ borderland) this Note has considered. Quantitative data 
judicial doctrines to resolve disputes in the area and of the general success of mechanical tests in the evolution of the Code. Second, the economic benefits of the new standard outweigh any possible tax avoidance costs. The capital gains category has been devoid of economic cogency for far too long. Seeking to achieve such cogency, this Note has based capital gains preference on a policy of favoring long investors. With such a clear motivation, it should be much easier for the Service and the courts to police residual instances of misuse of the preference, as well as to formulate guidelines for new situations as they are presented.

\section{Appendix: A Proposed Regulation for the Spreading of RECEIPTS STANDARD}

The proposed modification would create a new subsection to be added as Treas. Reg. $\$ 1.1221-1(f) .{ }^{141}$ It would also be necessary to amend the existing Treas. Reg. $\$ 1.1221-1(a)$, second sentence, by adding the italicized words: "In determining whether property is a 'capital asset,' the period for which held is immaterial except as this period enters into the formula of $\S 1.1221-1(f)$ in doubtful cases."

Proposed text for $\$ 1.1221-1(f) .^{142}$ For contract termination payments and assets whose classification under section $1221(\mathrm{I})$ is ambiguous, the following "spreading of receipts" formula shall be applied to determine capital asset status. The rule shall be construed strictly against the taxpayer $^{143}$ in the sense that uncertainties arising in its application, and particularly from projection of the future segment of receipts, shall be resolved in the sense least favorable to the taxpayer.

(1) In general. (i) To apply the spreading of receipts formula, the gross receipts attributable to the asset disposed of are first arranged in a stream of quarterly gross receipts. This stream will in general have two segments: a

bearing out this litigation pressure may be amassed by counting numbers of citations to each of the leading judicial theories analyzed in Part I supra: Corn Prods. Refining Co. v. Commissioner, 350 U.S. 46 (1955), leads the field with 211 citations in 1955.71 (13.2 citations per year), see 3 Shepard's United States Citations: Case Edition Supplement 19431971, at $412-13$ (5th ed. 1971) [hereinafter U.S. Citations]. By comparison, Hort v. Commissioner, 313 U.S. 28 (1941), was cited 137 times in 1943-71, an average of 4.8 citations per year. See U.S. Citarions, supra at 916. Commissioner v. Ferrer, 304 F.2d 125 (2d Cir. 1962), received 24 citations through 1969, an average of three citations per year. See 3 Shepard's Federal Citations: Federal RePorter 520 (6th ed. 1969). In seeking to cut back on this volume of litigation, as well as to ease planning difficulties in the area, the Clifford rules are the model that has most directly inspired the present proposal. See notes 69 \& 125 supra (history of Clifford area). See also Brudney \& Chirelstein, Fair Shares in Corporate Mergers and Takeovers, 88 HARv. L. REV. 297 (1974) (brightline "fairness formula" proposed to govern the partition of synergistic gain from mergers not at armslength).

141. The intent is for the Regulation to be passed under the authority of an enabling statute such as that suggested in note 68 supra (and modeled on I.R.C. $\$ 1502$ ).

142. Bracketed statements in following text are not part of the text of the Regulation, but are intended as aids to the reader.

143. This would serve to cover the situations discussed in note 82 supra. 
past segment, starting with the receipts that were attributable to the asset during the quarter of the first taxable year in which the disposing owner acquired the asset (hereinafter the "starting quarter"), and a future segment that projects the fair market value of the receipts that are expected to be attributable to the asset in each future quarter of its remaining productive lifetime as of the time of disposition, so that the last receipt in the future stream is the salvage value of the asset, if any. This projection is to be carried out in the assumed absence of repair or other replacement investment.

(ii) Compute total receipts by adding all past and all future receipts determined under (i). Part of this total will thus consist of actual (realized) receipts and part of future (expected) receipts.

(iii) For each past and future quarter, compute the fraction of the total receipts attributable to that quarter by dividing the receipts realized, or projected, for that quarter by the total receipts computed under (ii).

(iv) Multiply each fraction computed in (iii) by the elapsed number of quarters since the beginning of the starting quarter defined under (i). Thus, for the starting quarter itself, one obtains the number of dollars received in that quarter divided by total receipts; for the second quarter, twice the number of dollars received in that quarter divided by total receipts; for the third quarter, three times the number of dollars received in that quarter divicled by total receipts, and so on. Add all these quantities, commencing with the starting quarter and continuing through the last (normally future) quarter in the projected productive lifetime of the asset. [The result is a quantity that may be directly interpreted as the average deferral period associated with dollars of gross receipt attributable to the asset, as measured in time elapsed from the beginning of the starting quarter.]

(v) Multiply each fraction in (iii) by the square of the difference between (1) the number of quarters elapsed since the beginning of the starting quarter and (2) the average deferral period calculated under (iv). [The resulting quantity will be positive (or zero) in all cases, since the square of any number, positive or negative, is never negative.] Add the resulting positive quantities over all quarters in both the past and the future parts of the stream.

(vi) Take the square root of the sum described in (v). [This is the statistical standard deviation of deferral times associated with the stream of past and projected future receipts attributable to the asset, and measures the spreading of receipts attributable to the asset.]

(vii) Assign capital asset status to the asset if and only if the standard deviation computed in (vi) exceeds six quarters ( 1.5 years). ${ }^{144}$

(2) Examples. [Here an actual Regulation would work out at least three or four examples. Because development of such examples would be lengthy, the reader is referred to Section III. B supra (applications of the test to leading cases) and notes 82, 83, 85, 96 \& 102 supra (illustrating how the test is applied arithmetically).]

144. Alternatively, step (vi) could be eliminated, and the quantity obtained at the end of step (v) directly compared with $(1.5)^{2}=2.25$. See note 81 supra. This modification would not change the tax result in any case. 